The Social Sciences 7 (4): 502-509, 2012

ISSN: $1818-5800$

(C) Medwell Journals, 2012

\title{
The Permissibility Status of Plant Biotechnology from the Islamic View
}

\author{
${ }^{1,2}$ Latifah Amin, ${ }^{2,4}$ S. Siti Fairuz, ${ }^{3}$ Abdul Latif Samian, ${ }^{2}$ Mohamad Sabri Haron, \\ ${ }^{4}$ Mohd Nasran Mohamad and ${ }^{5}$ Mohd Yusof Othman \\ ${ }^{1}$ Social Impact of Biotechnology Development in Malaysia (SIMBIO) Research Group, \\ ${ }^{2}$ Centre for General Studies, ${ }^{3}$ Institute of The Malay World and Civilization (ATMA), \\ ${ }^{4}$ Faculty of Islamic Studies, ${ }^{5}$ Institute of Islam Hadhari, \\ Universiti Kebangsaan Malaysia, 43600 UKM Bangi, Selangor, Malaysia
}

\begin{abstract}
The development of modern biotechnology has the potential to enhance the quality of the industrial, medical and agricultural sectors worldwide. However, it has created a divisive debate globally on its positive and negative impacts. The objective of this study is to assess the permissible status of interspecies gene transfers in plant biotechnology from the Islamic perspective. This study involved the identification and interpretation of the verses from al-Quran and quotations from al-Sunnah and the analysis of other relevant Islamic sources. The permissible status of food derived from plant biotechnology according to the Islam perspective must fulfill the concept of halalan tayyiban. Halalan tayyiban refers to the permissible status of food in relation to Syariah or the Islamic law. There are two important parts in determining the status of halalan tayyiban for plant biotechnology products the beginning process (input) or the gene sources and the final process (output) which refers to the direct or indirect impact of the final products to the five objectives of syariah. In conclusion from the Islamic point of view, the development of modern biotechnology is permitted if the inserted genes are taken from halal (permissible) sources and at the same time it does not cause any harmful effects to the five objectives of syariah.
\end{abstract}

Key words: Plant biotechnology, cross-species gene transfer, Islamic perspective, halalan tayyiban, harmful effect, Malaysia

\section{INTRODUCTION}

Biotechnology is a technology based on biology, especially when used in agriculture and food science to provide goods and services (Haggag, 2008). It has existed along with the existence of human being on earth. The innovation in biotechnology has focused more on medical research, food processing industry and agriculture (Barnum, 2005). This technology allows the scientists to produce a variety of the best plant breeds and on the other hand, modern biotechnology improves the plants quality by manipulating the DNA genes (Wieczorek, 2003). The rapid development in biotechnology has reached a stage where scientists can applied a technique called recombinant DNA to identify, select and modify DNA sequences to attain specific genetic features for example insect resistance genes from donor organisms (either from microorganism, plant or animal) and transfer the DNA sequence into recipient organism which can express the nature of the inserted genes (Vento and Gillum, 2002; WHO, 2005). Modern biotechnology products are called Genetically Modified Organisms (GMOs) or transgenic organisms. This method is used to produce Genetically Modified (GM) plants (Vento and Gillum, 2002; Wieczorek, 2003; WHO, 2009).

One of the ultimate goals in developing modern biotechnology is to overcome the problem of starvation and food shortages, especially in poor countries (Carpenter et al., 2002). Improvements in the quality of GM plants include the improvement of structural shape, colour and better taste as well as long lasting and not easily damaged crops and produce such as Flavr Savr tomato (Wieczorek, 2003; Barnum, 2005; Holder, 2006). Improvements in terms of nutrition such as the production of golden rice which contains higher vitamin A content to overcome blindness in children has been achieved (Wieczorek, 2003).

GM plants can also be tailored to elevate its own safety whereby they can protect themselves from diseases which come from virus or insect pests and herbicides (Holder, 2006). This in turn can reduce the reliance on pesticides and herbicides as they are

Corresponding Author: Latifah Amin, Social Impact of Biotechnology Development in Malaysia (SIMBIO) Research Group, Universiti Kebangsaan Malaysia, 43600 UKM Bangi, Selangor, Malaysia 
dangerous if used in large quantities (Carpenter et al., 2002; WHO, 2009) and as a way out to overcome environmental degradation problem on air, earth, flora and fauna and the entire ecosystem (Carpenter et al., 2002). However, many questions have been raised among the Muslims on the permissibility status of GM foods while others were concerned about different kind of risks of GMOs to human health, environment and society.

As suggested by al-Qardhawi, in order to resolve the contradiction between risks and benefits of a new technology, the modern expert scholars such as the scientists has the duty to explain the current issues to the Muslim scholars before a principle or a guideline is established and gazetted. $\mathrm{He}$ has highlighted the importance of knowledge about fiqh among scientists and willingness and openness of Muslim scholars to discuss and resolve various issues that arise in contemporary Islamic principles. This is mainly due to any given statement given by a group of Islamic scholars will be a reference for the Muslim society (Bouzenita, 2008). An example is the legal statement by al-Qardhawi on genetic engineering and a statement from the Islamic Fiqh Academy (2000) that allows certain cloning techniques and genetic engineering in the microbiology field, botany and Zoology. Furthermore, the Muzakarah Fatwa Committee of the National Council for Islamic Affairs Malaysia has highlighted the permissibility status of things, food and drinks involving pig DNA biotechnology process. However, there are more uncertainties related to GM plants and products among the Muslims.

The acceptance of GM plants and products by the muslims worldwide depend on their permissibility status according to Islamic laws. The objective of this study is to assess the permisibility status of GM plants and product according to the concept of halalan tayyiban.

\section{THE CONCEPT OF HALALAN TAYYIBAN}

The Islamic perspective on food application can never be separated from the principle of halalan tayyiban. This principle explains not only on the needs of having or producing halal foods according to al-Quran but it concerns on the good quality of the foods which bring no harmful effects to human and the environment.

According to Shaikh Mohd Saifuddeen, Chief Executive Officer of Yayasan Ilmuwan who is an expert slamic laws, in order to achieve the established quality of GM food that meet the concept of halalan tayyiban, the GM food needs to fulfill this particular requirements of halal and good food. Both concepts of halal and tayyib can never be separated because there is no halal food which is not good and no food is good but not clean which in this case it is addressed as halal. Allah the Almighty says:

Say: Not equal are things that are bad and things that are good. Even though, the abundance of the bad may dazzle thee so fear Allah, O ye that understand that (so), ye may prosper (Surah alMaidah: 5: 100)

This is because many foods that have been processed may look good, clean, tempting and satiating but could be unhealthy. Moreover, some foods could cause long term negative effect for example junk food and pickles which have been reported to cause diabetes, obesity and cancer. In certain cases, halalan tayyiban has to assesed on the individual basis. As an example, the Brazil nut gene which has been inserted into GM soy bean might probably be halalan tayyiban to a certain consumer but the concept of halalan tayyiban is not applicable to those who are allergic to Brazil nuts and any products based on Brazil nuts. This is because it will bring harmful effect to them.

Al-Qardhawi stated that every muslims is forbidden to eat food or drink liquid which can cause damage or dangerous to their health before the food receives safety and health approval by the food regulatory authority (Radzi, 2000).

Based on this statement, GM food has not yet received the status of halalan tayyiban as it has not achieved its safety and health status yet. The halal status of certain things is an indication of approval from Allah. Meanwhile, the concept of tayyib covers all aspects of good and quality food that is not only clean and healthy but it must also be safe for human consumption for a long term period.

The halalan tayyiban basis for the determination of GM foods should be based on two important aspects which are the original sources of inserted genes and the final effect of the product.

\section{THE BEGINNING PROCESS (INPUT)}

The legal determination of GM plants depends on the intention of individuals or companies that operate them. Intention or faith plays a vital role as it is the main key to differentiate how certain action is considered as good or negative and it will be measured by Allah in the hereafter to either receive rewards or punishment based on his or her intention to do the actions.

Every practice should begin with good faith because of Allah and done in a positive way consistently and as consequences will bring good results and vice versa. It 
has been narrated on the authority of Umar al-Khattab that the messenger of Allah (may peace be upon him) said:

The value of an action depends on the intention behind it. A man will be rewarded only for what he intended (Muslim: Kitab al-Imarah Bab: Bab qauluhu bi al-niat: 1907)

A legal determination of halal products should start from the original source of the genes. There are several gene sources that can be. Genes inserted into plants can be derived from several sources such as from plants, animals, human or microorganisms.

Genetically modified foods containing genes derived from plant: $\mathrm{M}$ plants containing genes derived from plant for food consumption are permitted in Islam. According to Muhammad, GM plants are halal as long as they and heir products do not bring harmful side effects. In Islamic law, if GM plants were proved to be damaging to humans and other creatures, the GM plants or products will be considered as prohibited (Bouzenita, 2007). This is as Allah says SWT:

Saying: Eat of the good things we have provided for your sustenance but commit no excess therein, Lest My wrath should justly descend on you and those on whom descends My wrath do perish indeed (Surah Taha: 20:81)

Genetically modified foods containing genes derived from animals: When the plant is inserted with genes from animals, the lawful status of the GM plants are based on the legal Islamic law of the origin of the animals. The second criteria that has to be fulfilled is the effect of the product which should not bring any harm to human and other living things.

Legal animals in Islam: Animals that are clearly lawful in Islam are the animals which are permissible according to al-Quran and al-Sunnah such as cattle, goats, camels and sheeps which are slaughtered in the name of Allah, as well as fish and locusts. This statement is based on the word of Allah SWT says in Surah al-Maidah:

O ye who believe! Fulfill (all) obligations. Lawful unto you (for food) are all four-footed animals with the exceptions named but animals of the chase are forbidden while ye are in the sacred precincts or in pilgrim garb for Allah doth command according to His will and plan (Surah al-Maidah: 5: 1)
Lawful to you is the pursuit of water-game and its use for food, for the benefit of yourselves and those who travel but forbidden is the pursuit of land-game; As long as ye are in the sacred precincts or in pilgrim garb and fear Allah, to whom ye shall be gathered back (Surah alMaidah: 5: 96)

Illegal animals in Islam: Animals that are classified as illegal according to the al-Quran and al-Sunnah are swine, dead animals, blood, human, wild animals and animals that were slaughtered without pronouncing the name of Allah. This is supported by the Quranic verse and quotation from al-Sunnah:

He has only forbidden you dead meat and blood and the of swine and any (food) over which the name of other than Allah has been invoked. If one is forced by necessity without willful disobedience nor transgressing due then Allah is oft-forgiving Most Merciful (Surah an-Nahl: 16: 115)

We have honored the sons of Adam; provided them with transport on land and sea; given them for sustenance things good and pure and conferred on them special favours, above a great part of Our creation (Surah al-Isra: 17: 70)

Abu Huraira reported Allah's Messenger (may peace be upon him) as saying: The eating of all fanged beasts of prey is unlawful (Muslim: Kitabalsaid wa al-zabaih wa yukalu min al-hayawan: Bab tahrim akala zi nab min al-sibai wa kullu mahlab min thoir: 4751).

Animals that are doubtful in Islam: Animals that are of questionable status such as insects is included in the category of animals that are not otherwise lawful or unlawful status of al-Quran and al-Sunnah. Determination of the law for this unknown status of animals refers to the basis of istibahah asliyah. The Prophet Muhammad cited:

Narrated Abdullah Ibn Abbas: The people of pre-Islamic times used to eat some things and leave others alone considering them unclean. Then Allah sent His Prophet (peace be upon him) and sent down His Book marking some things lawful and others unlawful so what He made lawful is lawful what he made unlawful is unlawful and what he said nothing about is allowable (Abu Daud: Kitab al atimah: Bab ma la yuzkar tahrimihi: 3794) 


\section{THE FINAL EFFECT (OUTPUT)}

Zaydan in his book al-Mufassal fi Ahkam al-Marah wa Bait Muslim fi al-Syariah al-Islamiyyah noted that food will not be considered haram as long as there is no legal indications or dalil that shows it is haram and clearly can cause damages to humans. This shows that eventhough the original source is halal and the food has undergone a good process but if the product of GM plants is found out to bring damages or any harmful effects to humans and other living things it can fall into haram (Bouzenita, 2008). Al-Salam said if the final process or output resulting damages on earth, it is actually a punishment of sinful acts done by humans themselves. Allah the Almighty says:

Whatever misfortune happens to you is because on the things your hands have wrought (Surah as-

Syuraa: 42: 30)

Thus to ensure that the halalan tayyiban concept is applicable to GM products, they should be based on the five purposes of Islamic law. The five purposes are preservation of religion, health, progeny, intellect and wealth. Any modern biotechnology application/product must fulfill at least one of the purposes if it is to be permitted. However if any GM application/product violates any of the five purposes it should not be permitted.

Preservation of religion and morality (Hifz al-Din.): Ibadah or worship produces such as salah, zakah, fasting and hajj are the elements that are required for the maintenance of the very existence of al-Din (Masud, 1977). Executing all these rituals will increase the faith (Iman) of a person and will therefore be a shield to protect the person from committing sin or becoming apostate and indulging in any action that will obliterate his al-Din (Laldin, 2008). The responsibility to protect al-Din falls under the category of preventing evil.

Preservation of life and health (Hifz al-Nafs): The second purpose of Islam is protection of life and health (Hifz alNafs). Life is essential and valuable to everyone. Protecting everyone's life is equally important and obligatory to each and every individual and society (Laldin, 2008). To maintain high quality of life (Kasule, 2004), life must be protected in all circumstances.

Preservation of progeny (Hifz al-Nasl): The 3rd purpose in Islam is protection of progeny or Hifz al-Nasl (Kasule, 2004). Progeny is one of the essential elements of a person in the his or her life (Laldin, 2008). The insistence of Shariah on preservation of the progeny is intended for ensuring inter-generational equity in the distribution of wealth and prosperity, conservation of resources and sustenance of the environment (Hasan, 2006).

Preservation of intellect or mind (Hifz al-Aql): The 4th purpose in Islam is protection of the mind or intellect, Hifz al-aql (Kasule, 2004). Al-Aql is a great gift from Allah to mankind. This is one of the human capacities that differentiate man from animals. Allah has ordered that everyone should protect this precious gift from Allah by utilizing the mental for the benefit of all and not for any kind of evil or anything that might lead to destruction (Laldin, 2008). Protection of mind requires safeguarding it from anything that might harm the ability and function of brain. Anything that can avoid or disturb intellect to get knowledge should be avoided (Nyazee, 2004).

Preservation of wealth or property (Hifz al-Mal): The 5th purpose in Islam is protection of wealth or property Hifz al-Mal. Property is one of the necessities of mankind. Everyone has his/her own property and would like to have all the necessary protection and security for his/her property. Islam has ordered that no one should transgress and acquire the property of others without legitimate reasons and without proper contract (Laldin, 2008). Wealth is secured by creating proper conditions and encouraging its growth (Nyazee, 2004). Shariah encourages work and trading activities in order to enable the individual to earn a living and it prescribes elaborate measures to ensure the smooth flow of commercial transactions in the market-place. The violation of wealth such as by theft or misappropriation of wealth should be prevented.

\section{APPLYING THE CONCEPT OF HALALAN TAYYIBAN TO GM PLANTS}

Genetically modified foods containing genes derived from plant: If the genes are derived from plant and they are being transfer to another plant, the GM plant products are permitted in Islam for food consumption. An example in the use of plant genes to be inserted into another plant is the insertion of carrot gene into paddy to produce the vitamin A enhanced golden rice (Tang et al., 2009). As long as Golden rice does not cause any harmful effects to the five objective of Syariah so it is safe and permissible to eat it. However, if the use of the genes and its products bring any harm such as the insertion of the Brazil nut gene into soybean that caused allergies (Nordlee et al., 1996). Some individuals are allergic to this nut that can make them to go into anaphylactic shock which can caused 
death (Nordlee et al., 1996). So, the GM food should not be allowed to be commercialized. From the view of Maqasid al-Syariah even if sources of gene was halal but the products bring concerns or risks to human such as allerginicity, toxicity, unknown effects and threat to human health (Cummins, 2002) then the products are considered as totally against the 2nd purpose in Islam which is preservation of life and health (Hifz al-Nafs).

\section{Genetically modified foods containing genes derived from animals}

Legal animals in Islam: The uses of genes from legal animals in plants are permitted provided the GM plants do not bring harmful effects to human and other living organisms. For example, the use of gene fish in the GM tomatoes were permissible but after it was found that it affected the health in become illegal in Islam then the GM tomatoes were withdrawn from the market (Barnum, 2005; FAO, 2010). From the point of view of Maqasid al-Syariah, even if halal gene sources were used but if the GM plant/products are found to be risky such as toxic and threaten human health then the GM plants/products are totally against the 2nd purpose in Islam which is preservation of life and health (Hifz al-Nafs).

Illegal animal in Islam: The use of genes derived from the illegal sources such as swine gene into plant and human gene should be avoided. An example is the use of swine gene in GM rice nicknamed as Nihonbaree rice to confer herbicide resistance (Kawahigashi et al., 2005) and the use of human growth hormone gene in GM rice (Kim et al., 2008) are not permitted. The prohibition on the use of genes derived from illegal sources is consistent with the opinion of the special muzakarah held by the Fatwa Committee of the National Council for Islamic Affairs of Malaysia on July 12, 1999. The muzakarah ruled that the use of swine genes through biotechnology techniques in the processing of goods, food and drink is contrary to Islamic principles and the is illegal.

From the point of view of Maqasid al-Syariah, the use of haram sources even if the outputs are beneficial to human are totally against the first purpose in Islam which is preservation of religion (Hifz al-Din.) This is because the prohibition to use it is clearly mentioned in al-Quran and al-Sunnah. So, as muslim we must obey all Allah commands.

Sources that is doubtful in Islam: The use of bacterial or viral gene in plants is still uncertain and should refer to local custom and the output. If the GM plant/product that contains bacterial or viral genes is proven as harmful to human and environment then it should not be allowed. As an example the Environmental Protection Agency (EPA) did not approve StarLink corn because it contained Cry9c protein which cause allergic reactions.

For example, even if the local custom accept the use of gene from sources that are not clear whether legal or illegal in Islam but at the same time it bring negative impact to human and the environment, disturb the balance of nature (Polkinghorne, 2000), give direct and indirect effects of toxic transgenes to non-target organisms (Hilbeck et al., 2000), transgene escape to crop landraces and wild relatives through gene flow and its potential ecological consequences (Snow et al., 2005) and potential to create new herbicides resistance weed (Cummins, 2002). So, all these concerns seem to be against the preservation of progeny and the sustainability of this world (Hifz alNas1).

Other concerns of GM products: Other concerns of GM products that show it is against the 4th purpose in Islam which is preservation of intellect or mind (Hifz al-Aql) are the lack of data and little information about safety and health hazards in GM crops (Pustzai et al., 2003). According to Domingo (2000), no peer reviewed publications of clinical studies on the human health effects of GM food exist. Even animal studies are few and far in between. As a solution, these safety and toxicity studies of GM foods must be carried out by biotechnology companies and they also must publish the results of studies on the safety of GM foods in international peer-reviewed journals situation to help consumers make informed decisions before consuming any genetically modified products (Domingo, 2000).

For another example that show GM product against the forth purpose in Islam which is preservation of wealth or property (Hifz al-Mal) are when farmers must sign an agreement to restricting their use pay technology fees and not allow saving and replanting the genetically modified seed (GAO, 2000; Slater et al., 2003). Moreover, the UK Soil Associations news report cited that farmers are reporting lower yields, continuing dependency on herbicides and pesticides, loss of access to markets and critically, reduced profitability leaving food production even more vulnerable to the interests of the biotechnology companies and in need of subsidies (UK Soil Association, 2002). The application of halalan tayyiban concept in GM plants can be shown in Table 1.

Therefore, the development of GM plants need to be planned carefully so that the biodiversity sources could 
The Soc. Sci., 7 (4): 502-509, 2012

Table 1: The application of halalan tayyiban concept in GM plants

\begin{tabular}{lll}
\hline The original gene source & Output & Principle \\
\hline Plants to plant gene transfer & $\begin{array}{l}\text { GM plants, } \\
\text { proven safe } \\
\text { GM plants } \\
\text { harmful } \\
\text { GM plants, } \\
\text { proven safe }\end{array}$ & Halal \\
$\begin{array}{l}\text { Halal animals to plant gene transfer } \\
\text { Ex: Any type of animals }\end{array}$ & Halal \\
$\begin{array}{l}\text { which fall under the category of } \\
\text { al-Anam (cattle, goats, camels, } \\
\text { sheep) slaughtered according to }\end{array}$ & Harmful \\
$\begin{array}{l}\text { Islamic law, fish and locusts } \\
\text { Haram animals to plant gene transfer }\end{array}$ & $\begin{array}{l}\text { GM plants, } \\
\text { Ex: Swine, slaughtered } \\
\text { animals without mentioning }\end{array}$ & Haram safe \\
$\begin{array}{l}\text { Allahs name, wild animals and } \\
\text { humans }\end{array}$ & $\begin{array}{l}\text { GM plants } \\
\text { harmful }\end{array}$ & Haram \\
$\begin{array}{l}\text { Sources that were not categorized } \\
\text { whether halal or haram status in } \\
\text { al-Quran }\end{array}$ & $\begin{array}{l}\text { GM plants } \\
\text { proven safe }\end{array}$ & $\begin{array}{l}\text { Refer to } \\
\text { societal }\end{array}$ \\
& acceptance \\
\hline
\end{tabular}

be fully used only as much as necessary and does not lead to wastage or destruction. This is to ensure that development does not destroy the ecosystem, affect the food chain or threaten the life of species of flora and fauna (Batalion, 2000).

Thus, as long as GM foods do not meet the above mentioned requirements the GM foods are still categorized as a food syubhah. On the authority of Abu Abdullah al-Numan bin Bashir (radiyallahu anhu) who said: I heard the Messenger of Allah, sallallahu alayhi wasallam say:

Truly, what is lawful is evident and what is unlawful is evident and in between the two are matters which are doubtful which many people do not know. He who guards against doubtful things keeps his religion and honour blameless and he who indulges in doubtful things indulges in fact in unlawful things just as a shepherd who pastures his flock round a preserve will soon pasture them in it. Beware, every king has a preserve and the things Allah has declared unlawful are his preserves. Beware, in the body there is a flesh if it is sound, the whole body is sound and if it is corrupt the whole body is corrupt and behold it is the heart (Muslim; Kitab al-Musaqat; Bab Ahzi al-Halal wa Taraka al-Syubhat; 1599)

Allah reminds human to always be aware of evils temptation and seduction. This is because satan will always make efforts to fulfill their promises to seduce humans to do bad things and sinful acts. This is where devotion lies in humans. Servant, who believed and feared Allah be afraid to eat unclean food because it invites the wrath of God and this is what distinguishes faith and devotion of a human.
$O$ ye who believe! make not unlawful the good things which Allah hath made lawful for you but Commit no excess: for Allah loveth not those given to excess. Eat of the things which Allah hath provided for you lawful and good but fear Allah in whom ye believe (Surah al-Maidah: 5 :87-88)

However, GM food may be a need in the event of an emergency (a very desperate situation when there is no alternative situation). But, this situation is subject to certain conditions, namely:

- GM food can only be used as needed to relieve the emergency only, exceeding the limit might cause the GM food to fall under prohibition

- A particular harm shall not be removed by inflicting another harm

The need for GM food as emergency relieve is considered as irrelevant in Malaysia as Malaysia has no food shortage problem, there are various alternative technology or agricultural practices and the land in this country is fertile earth. However, for poor countries that suffered a very serious food crisis such as in Africa, they can be used in emergency situations. As mentioned by the President of Zimbabwe, they are in dilemma to either receive food aid from America with an unknown security status or allow his people to die of starvation (Walters, 2006).

\section{CONCLUSION}

Islamic principles require modern plant biotechnology to reach the standard concept of halalan tayyiban which is the ultimate yardstick in determining food principles in Islam. GM plant which achieves the quality of halalan tayyiban concept in Islam must abide with two conditions namely the original source is halal and the impact of the product is guaranteed to not causing any harmful effects to humans and environment.

However in emergency circumstances without other alternatives, GM food is considered legal as per necessary yet it still has to abide with certain conditions as stated in the previous sessions. Therefore, the advantages that human can gain from GM plant and food should not be wasted. On the other hand, the process applied should follow the Islamic principles so that it will bring many positive effects to humans and environment as a whole. 


\section{ACKNOWLEDGEMENT}

The researchers would like to thank Universiti Kebangsaan Malaysia for supporting this research under the UKM-GUP-JKKBG-08-10-042.

\section{REFERENCES}

Barnum, S.R., 2005. Biotechnology: An Introduction. 2nd Edn., Thomson-Brooks/Cole, Belmont, CA., ISBN: 9780495019275, Pages: 323.

Batalion, N., 2000. 50 Harmful effects of genetically modified foods. Americans for Safe Food, Oneonta, New York, USA. http:/www.scribd.com/doc/94672 03/50-Harmful-Effects-of-Genetically-ModifiedFoods.

Bouzenita, A.I., 2007. Eating the fruits of hubris? Biotechnology in food and consumer products-An Islamic perspective. Proceedings of the National Seminar on Biotechnology in Food and Consumer Products: Islamic Perspective, December 12, 2007, Department of Fiqh and Usul Al Fiqh, International Islamic University Malaysia.

Bouzenita, A.I., 2008. Change of Creation or Harnessing Nature? The Reception of Biotechnology in the Islamic World. In: Islamic Science and The Contemporary World: Islamic Science in Contemporary Education, Ahmad, B. (Ed.)., International Institute of Islamic Thought and Civilization, Kuala Lumpur, Malaysia, pp: 373-394.

Carpenter, J., A. Felsot, T. Goode, M. Hammig, D. Onstad and S. Sankula, 2002. Comparative Environmental Impacts of Biotechnology-derived and Traditional Soybean, Corn and Cotton Crops. 1st Edn. Council for Agricultural Science and Technology, Ames, IA, USA.

Cummins, R., 2002. Hazards in Genetically Modified Foods and Crops: Why we Need a Global Moratorium. In: Ethical Issues in Biotechnology, Sherlock, R. and J.D. Morrey (Eds.)., Rowman and Littlefield Publishers Inc., USA., pp: 213-221.

Domingo, J.L., 2000. Health risks of genetically modified food: Many opinions but few data. Science, 288: 1748-1749.

FAO., 2010. FAO Statement on Biotechnology. Food and Agriculture Organization of the United Nations. http://www.fao.org/biotech/stat.asp.

GAO, 2000. Information on Prices of Genetically Modified Seeds in the United States and Argentina, US. General Accounting Office, Washington, DC., USA.

Haggag, W.M., 2008. Biotechnological aspects of plant resistant for fungal diseases management. Am. Eurasian J. Sustainable Agric., 2: 1-18.
Hasan, Z., 2006. Sustainable development from an Islamic perspective: Meaning, implications and policy concerns. Islamic Econ., 19: 318-318.

Hilbeck, A. and M.S. Meier and A. Raps, 2000. Review on non target organism and $\mathrm{Bt}$ plants. Report to Greenpeace International, Amsterdam, EcoZtrar $\mathrm{GmbH}$. Zurich, Switzerland.

Holder, B., 2006. Defining genetically engineered organisms. Genetically Engineered Organisms and the Environment: Report of the ENVS 4800 Critical Thinking 2006 Class, pp: 9-11. http://envs colorado. edu/uploads/undergrad/GMO sm.pdf.

Islamic Fiqh Academy, 2000. Resolutions and Recommendations of the Council of the Islamic Fiqh Academy 1985-2000. 1st Edn., Islamic Development Bank, Jeddah, Saudi Arabia, Pages: 269.

Kasule, O.H., 2004. Medical ethics from Maqasid A1Shari'at. Arab, J. Psychiatry, 15: 75-86.

Kawahigashi, H., S. Hirose, K. Ozawa, Y. Ido, M. Kojima, H. Ohkawa and Y. Ohkawa, 2005. Analysis of substrate specificity of pig CYP2B22 and CYP2C49 towards herbicides by transgenic rice plants. Transgenic Res., 14: 907-917.

Kim, T.G., M.Y. Baek, E.K. Lee, T.H. Kwon and M.S. Yang, 2008. Expression of human growth hormone in transgenic rice cell suspension culture. Plant Cell. Rep., 27: 885-891.

Laldin, M.A., 2008. Introduction to Shari'ah and Islamic Jurisprudence. Centre for Research and Training, Kuala Lumpur, Malaysia.

Masud, M.K., 1977. Islamic Legal Philosophy: A Study of Abu Is?aq Al-Sha?ibi's Life and Thought. The Islamic Research Institute, Islamabad, Pakistan.

Nordlee, J.A., S.L. Taylor, J.A. Townsend, L.A. Thomas and R.K. Bush, 1996. Identification of a Brazil nut allergen in transgenic soybeans. New Eng. J. Med., 334: 688-692.

Nyazee, I.A.K., 2004. Islamic Jurisprudence. Adam Publishers and Distributor, New Delhi, India.

Polkinghorne, J.C., 2000. Ethical issues in biotechnology. Trends Biotechnol., 18: 8-10.

Pustzai, A., S. Bardocz and S.W.B. Ewen, 2003. Genetically Modified Foods: Potential Human Health Effects. In: Food Safety Contaminants and Toxin, D'Mello, J.P.F. (Ed.). CABI Publisher, UK., pp: 347-372.

Radzi, CWJWM, 2000. Konsep Kesihatan Melalui Pemakanan: Pendekatan Islam Dan Sains. Utusan Publication and Distributors Sdn. Bhd., Kuala Lumpur, Malaysia, Pages: 150.

Slater, A., N.W. Scott and M.R. Fowler, 2003. Plant Biotechnology: The Genetic Manipulation of Plants. Oxford University Press, New York, USA., ISBN-13: 978-0199254682, pp: 35-52. 
Snow, A.A., D.A. Andow, P. Gepts, E.M. Hallerman, A. Power, J.M. Tiedje and L.L. Wolfenbarger., 2005. Genetically engineered organisms and the environment: Current status and recommendations. Ecol. Appl., 15: 377-404.

Tang, G., J. Qin, G.G. Dolnikowski, R.M. Rusell and M.A. Grusak, 2009. Golden rice is an effective source of vitamin A. Am. J. Clin. Nutr. 89: 1776-1783.

UK Soil Association, 2002. Seeds of Doubt: North American Farmers Experience of GM Crops. UK Soil Association.

Vento, A.B. and D.R. Gillum, 2002. Fact sheet describing recombinant DNA and elements utilizing recombinant DNA Such as plasmids and viral vectors and the application of recombinant DNA techniques in molecular biology. University of New Hampshire. http://www.unh.edu/ehs/pdf/Recombinant-DNA.pdf.
WHO, 2005. Modern food biotechnology, human health and development an evidence based study. Food Safety Depart, World Health Organization, Geneva, Switzerland.

WHO, 2009. 20 questions on Genetically Modified (GM) foods. World Health Organization. Geneva. http:/www.who.int/foodsafety/publications/biotec $\mathrm{h} / 20$ questions/en/.

Walters, R., 2006. Crime, bio-agriculture and the exploitation of hunger. Brit. J. Criminol., 46: 26-45.

Wieczorek, A., 2003. Use of biotechnology in agriculturebenefits and risks. Biotechnology; $\mathrm{BIO}-3$, University of Hawaii, Honolulu HI., pp: 1-6. http://www.ctahr. hawaii.edu/oc/freepubs/pdf/BIO-3.pdf. 